\title{
Insulin translates unfavourable lifestyle into obesity
}

Hubert Kolb ${ }^{1,2}$, Michael Stumvoll ${ }^{3}$, Werner Kramer ${ }^{4}$, Kerstin Kempf $^{2^{*}}$ and Stephan Martin ${ }^{1,2}$

\begin{abstract}
Lifestyle factors conferring increased diabetes risk are associated with elevated basal insulin levels (hyperinsulinaemia). The latter predicts later obesity in children and adolescents.

A causal role of hyperinsulinaemia for adipose tissue growth is probable because pharmacological reduction of insulin secretion lowers body weight in people who are obese. Genetic inactivation of insulin gene alleles in mice also lowers their systemic insulin levels and prevents or ameliorates high-fat diet-induced obesity. Hyperinsulinaemia causes weight gain because of a physiological property of insulin. Insulin levels that are on the high side of normal, or which are slightly elevated, are sufficient to suppress lipolysis and promote lipogenesis in adipocytes. The effect of insulin on glucose transport or hepatic glucose production requires six or two times higher hormone levels, respectively.

It seems justified to suggest a lifestyle that avoids high insulin levels in order to limit anabolic fat tissue activity.
\end{abstract}

Keywords: Insulin, Hyperinsulinaemia, Obesity, Type 2 diabetes mellitus, Lipolysis, Lifestyle

\section{Background}

\section{Lifestyle, systemic inflammation and hyperinsulinaemia}

There are now more overweight people in the world than those who are underweight [1]. There has also been a major increase in the global prevalence of type 2 diabetes mellitus (T2DM) [2]. Lifestyle changes are commonly held responsible for these epidemics, with energydense western-style diets and little physical activity being major risk factors. However, other lifestyle factors may confer risks of both obesity and T2DM [3]. All factors are associated with moderately elevated systemic levels of pro-inflammatory mediators, increased fasting levels of insulin and decreased insulin sensitivity. Calorie-rich diets caused postprandial inflammation and hyperinsulinaemia $[4,5]$. Continuous excess nutrition more than doubled basal insulin levels within 4 days, but did not cause elevated basal glucose levels [6]. Increased physical activity or reallocation of sedentary time to physical activity lowers fasting insulin concentrations and the level of systemic inflammation [7]. Conversely, short-term decreased physical activity, with increased sedentary behaviour, increased whole-body insulin resistance [8]. In an experimental

\footnotetext{
* Correspondence: kerstin.kempf@wdgz.de

${ }^{2}$ West German Centre of Diabetes and Health, Duesseldorf Catholic Hospital

Group, Hohensandweg 37, 40591 Duesseldorf, Germany

Full list of author information is available at the end of the article
}

setting, exposure to road traffic-associated fine particulate matter was associated with higher levels of inflammatory markers, insulin and insulin resistance [9]. Sleep deprivation, even for one night, increases systemic insulin resistance $[10,11]$ and is accompanied by systemic inflammation [12] (Table 1). Although only studied using epidemiological approaches, a positive association has been observed between smoking, depression, stress or low socioeconomic status and inflammation or hyperinsulinaemia/insulin resistance [13-18].

Largely independent of obesity status, inflammation appears to be a rapid response to an unfavourable lifestyle $[19,20]$ and may be responsible for metabolic deterioration. For instance, low levels of pro-inflammatory cytokines such as interleukin-1 increased insulin secretion by $ß$-cells [21]. Pro-inflammatory cytokines interfere with insulin signalling; for example, the induction of IкB kinase $B$, which phosphorylates serine residues of IRS-1 and thereby interferes with insulin signalling [22, 23].

Several other pathways may be involved in promoting obesity by environmental/lifestyle factors; e.g., the hypothalamic-pituitary-adrenal axis, because increased cortisol exposure enhances fat accumulation in visceral depots [24]. Hypothalamic circuits contribute to appetite regulation and energy homeostasis [25]. Recently, glial and endothelial cells have reportedly contributed to

(c) The Author(s). 2018 Open Access This article is distributed under the terms of the Creative Commons Attribution 4.0 International License (http://creativecommons.org/licenses/by/4.0/), which permits unrestricted use, distribution, and reproduction in any medium, provided you give appropriate credit to the original author(s) and the source, provide a link to the Creative Commons license, and indicate if changes were made. The Creative Commons Public Domain Dedication waiver (http://creativecommons.org/publicdomain/zero/1.0/) applies to the data made available in this article, unless otherwise stated. 
Table 1 Association of obesity risk factors with low-grade systemic inflammation and hyperinsulinaemia

\begin{tabular}{llll}
\hline Lifestyle factor & Inflammation & $\begin{array}{l}\text { Hyperinsulinaemia/ } \\
\text { insulin resistance }\end{array}$ & References \\
\hline Calorie-rich diets & Yes $^{\text {a }}$ & Yes $^{\text {a }}$ & {$[4,5,114]$} \\
Sedentary time & Yes $^{\text {a }}$ & Yes $^{\text {a }}$ & {$[7,8,115]$} \\
Road traffic & Yes $^{\text {a }}$ & Yes $^{\text {a }}$ & {$[9,116,117]$} \\
Sleep deprivation & Yes $^{\text {a }}$ & Yes $^{\text {a }}$ & {$[10-12]$} \\
Smoking & Yes & Yes & {$[14,15]$} \\
Depression, stress & Yes & Yes & {$[13,16]$} \\
Low socioeconomic & Yes & Yes & {$[17,18]$} \\
status & & &
\end{tabular}

${ }^{\mathrm{a}}$ Randomised controlled trials indicate causal relationship

metabolic disorders and obesity [26, 27]. Genetic studies confirm the association between neurodevelopmental loci and obesity [28]. Another player is the microbiota [29]. Lipid fluxes and the liver are expected to affect the development of hepatosteatosis and obesity [30].

Independent of the initial effect of lifestyle factors, the pathway to obesity requires hyperinsulinaemia as a critical mediator in translating an unfavourable lifestyle into body weight gain.

\section{Main text}

Hyperinsulinaemia versus obesity: epidemiological findings Prospective studies exploring whether hyperinsulinaemia precedes and predicts later obesity have mostly been conducted in children and adolescents. Several studies found fasting hyperinsulinaemia and insulin resistance to be risk factors for weight gain in later years [31-35]. In a recent cohort that included $39 \%$ obese children, fasting hyperinsulinaemia did not predict change in body mass index (BMI), except for more weight gain in obese children [36]. Studies in adults do not offer consistent results. Fasting hyperinsulinaemia predicted weight gain in postmenopausal women, except in the most obese [37]. By contrast, high fasting insulin levels were associated with lower rates of weight gain in cohorts with a mean BMI of $26 \mathrm{~kg} / \mathrm{m}^{2}$ [38, 39] and in obese people [40, 41].

These results indicate that insulin levels may predict obesity in children and adolescents. Conclusions drawn from adult studies are less clear. However, these observational studies did not document and control for all lifestyle-dependent factors of obesity risk, all of which impact insulin secretion (Table 1). Only one study analysed dietary intake and an interaction was found between fasting insulin, total calories consumed, and fat percentage in predicting weight gain [42].

\section{Hyperinsulinaemia versus obesity: intervention trials}

A more direct approach for assessing the role of fasting (and diurnal) levels of insulin in weight gain includes interventions targeting insulin secretion. Insulin secretion can be partially inhibited with the potent $\beta$-cell $\mathrm{K}_{\text {ATP }}$ channel opener diazoxide [43]. In a randomised controlled trial, diazoxide in conjunction with a hypocaloric diet for 8 weeks led to greater weight loss in obese people than those in the control group treated by diet alone [44]. In the diazoxide group, insulin levels decreased by $36 \%$ (fasting) and $~ 55 \%$ (post intravenous glucose) without differences in blood glucose levels compared with the control. In a similar trial, diazoxide did not induce more weight loss than the hypocaloric diet alone in the control group [45]. Unfortunately, the baseline fasting insulin levels in this study were significantly higher in the diazoxide group (by 32\%) compared to the diet-alone group and the decrease in insulin secretion was not different between the diazoxide and control groups after 8 weeks of treatment. Taken together, body weight was reduced in all trials in which diazoxide achieved a lowering of basal and postchallenge blood glucose levels.

Insulin secretion can also be lowered by the long-acting somatostatin analogue octreotide. This peptide binds with high affinity to somatostatin receptors 5 and 2, effectively suppressing hormone production in $B$-cells and several other endocrine cells, such as those in the pituitary or gut [43]. Severely obese adults were treated for 24 weeks with a dose of octreotide that significantly suppressed insulin production (and possibly other hormones). Stimulated insulin indices were reduced by $57 \%$ and there was significant weight loss $(-3.5 \mathrm{~kg} /-2.8 \%)$ [46]. Secondary analyses showed that insulin was not significantly decreased in the subgroup with weight gain. By contrast, the remaining subgroup exhibited both a decrease in insulin secretion and substantial weight loss $(-5.6 \mathrm{~kg})$. In a subsequent similar study with three doses of long-acting octreotide and a randomised placebo control, the two higher doses caused significant weight loss $(-2.1 \mathrm{~kg} /-1.9 \%)$ compared with the control group $(-0.1$ $\mathrm{kg}$ ) [47]. As in the diazoxide trials, body weight reduction was only observed in association with lowered insulin levels.

Both compounds used to decrease insulin secretion have other pharmacological effects that may contribute to the weight loss observed. Diazoxide causes smooth muscle relaxation and fluid retention, while octreotide has a low risk of cardiac, hepatic and renal toxicity [48, 49]. However, the two drugs represent quite different pharmacological approaches, which share an insulin lowering effect but not adverse effects. Body weight reduction was only noted in conjunction with decreased insulin secretion.

In T2DM, treatment with exogenous insulin increases systemic insulin levels and this may support fat tissue growth [50]. The heterogeneous nature of T2DM means 
it is difficult to draw conclusions about the role of insulin or hyperinsulinaemia in a healthy metabolic state. Therefore, insulin therapy in type 1 or type 2 diabetes is not discussed here.

Increasing insulin concentrations in the brain appears to have opposite effects. Cerebral insulin is an anorexic hormone, but its actions are impaired in obese people because of brain insulin resistance [51]. Intranasal insulin delivery suppresses food intake and enhances postprandial thermogenesis, with concurrent lowering of postprandial systemic insulin levels $[52,53]$.

\section{Hyperinsulinaemia versus obesity: genetic studies}

Currently, selective lowering of circulating insulin levels without pharmacological effects in other organs can only be achieved by genetically manipulation. Mice harbour two insulin genes, Ins1 and Ins2. The tissue distribution pattern of Ins 2 resembles that of the human insulin gene, while Ins1 is expressed in ß-cells only. Glucose homeostasis remains normal after ablation of either insulin gene. After disrupting Ins2 and one allele of Ins1, fasting insulin was substantially reduced $(>50 \%)$ without persistent effects on glucose homeostasis [54]. When fed an obesogenic high-fat diet, these mice did not become obese, did not develop hepatic steatosis and increased energy expenditure in association with browning of white adipose tissue. In a second study, female mice with a deleted Ins 1 gene and only one intact Ins 2 allele exhibited lower insulin levels, but only during the first 6 months. However, this was sufficient to protect them from high-fat diet-induced obesity over one year of observation [55]. In a recent study using mice expressing only Ins2 (both alleles), mice exhibited compensatory high insulin production from Ins2 genes and developed obesity on a high fat diet. The Ins 2 gene had been modified to allow reduction of the insulin gene dosage by the Cre-loxP system. Partial ablation of Ins 2 alleles in adult obese mice led to significant weight loss, with a specific effect on visceral adipose tissue [56]. A moderate reduction in fasting insulin levels was seen (30\%) and did not affect glucose tolerance, insulin sensitivity, glucose-induced insulin secretion or body growth under a low or moderate fat diet. There were no differences in the levels of several other circulating hormones, including leptin, resistin, ghrelin, GIP, GLP-1, IL-6, and PYY.

The role of insulin in adipose tissue growth was also tested by selectively disrupting the insulin receptor gene in fat cells of white and brown adipose tissue. Such mice grew normally and their glucose tolerance was not different from control littermates. Basal glucose uptake into adipocytes was unchanged, but insulin-stimulated glucose uptake reduced by $\sim 90 \%$. Mice with such selective insulin resistance of adipose tissue had low fat mass and were protected from age-related obesity [57]. In summary, four different approaches to lowering insulin secretion had the same consequence: prevention or remission of obesity (Fig. 1).

Mutations of the human insulin gene have been described that affect insulin secretion. However, in all cases, insulin secretion was impaired to an extent that resulted in increased fasting glucose levels or diabetes [58-60].

\section{Hyperinsulinaemia: old findings reappraised}

Weight gain leading to an overweight BMI is usually caused by fat tissue growth rather than muscle. Ectopic storage of triglycerides in many other cell types, including liver and muscle cells, also contributes [61].

Insulin's lipogenic activity has been well studied and and is identical in concentration dependence to its inhibitory action on lipolysis; i.e., signalling through the insulin receptor on adipocytes causes simultaneous inhibition of lipolysis and storage of triglycerides [62]. One observation, first made in the 1980s, is that lower concentrations of insulin are required to inhibit lipolysis in adipocytes than are needed to promote glucose influx into peripheral tissue. In hyperinsulinaemic-euglycaemic studies, the concentrations of plasma insulin required to lower plasma levels of the products of triglyceride metabolism by $50 \%$ were $42-120 \mathrm{pmol} / \mathrm{l}$ (mean $=78 \mathrm{pmol} /$ 1), in non-obese subjects [63-69]. The mean fasting insulin level of all study groups combined was $48 \mathrm{pmol} / \mathrm{l}$; i.e., people with fasting insulin levels above the mean had substantially inhibited lipolysis. In another hyperinsulinaemic-euglycaemic study published in 1999, the inhibitory action of systemic insulin was similar between adipose and muscle tissue. Increasing insulin concentrations from 50 to $63 \mathrm{pmol} / \mathrm{l}$ already significantly inhibited glycerol release by around $20 \%$ [70].

Since most of these studies were North American, we compared figures with the normal range of fasting serum insulin levels of the representative National Health and Nutrition Examination Survey 1988-1994. Geometric mean fasting serum insulin levels for non-obese nondiabetic people were $\sim 46 \mathrm{pmol} / \mathrm{l}$ [71]. This suggests that more than half of the adult non-obese population in the USA had fasting insulin concentrations in the range required to inhibit $\geq 50 \%$ of lipolysis (Fig. 2). At the individual level, the relationship between insulin concentrations and lipolysis will be difficult to predict because of the substantial variation in fasting insulin concentrations (or insulin resistance) between non-obese people with varying genetic backgrounds and lifestyles [72]. Increased insulin resistance may attenuate increased lipolysis inhibition in people with higher fasting insulin levels. Such an interrelationship indeed exists, but two-thirds of the individual variation of insulin resistance cannot be explained by fasting insulin levels [73]. 


\section{Prevention/remission of obesity}

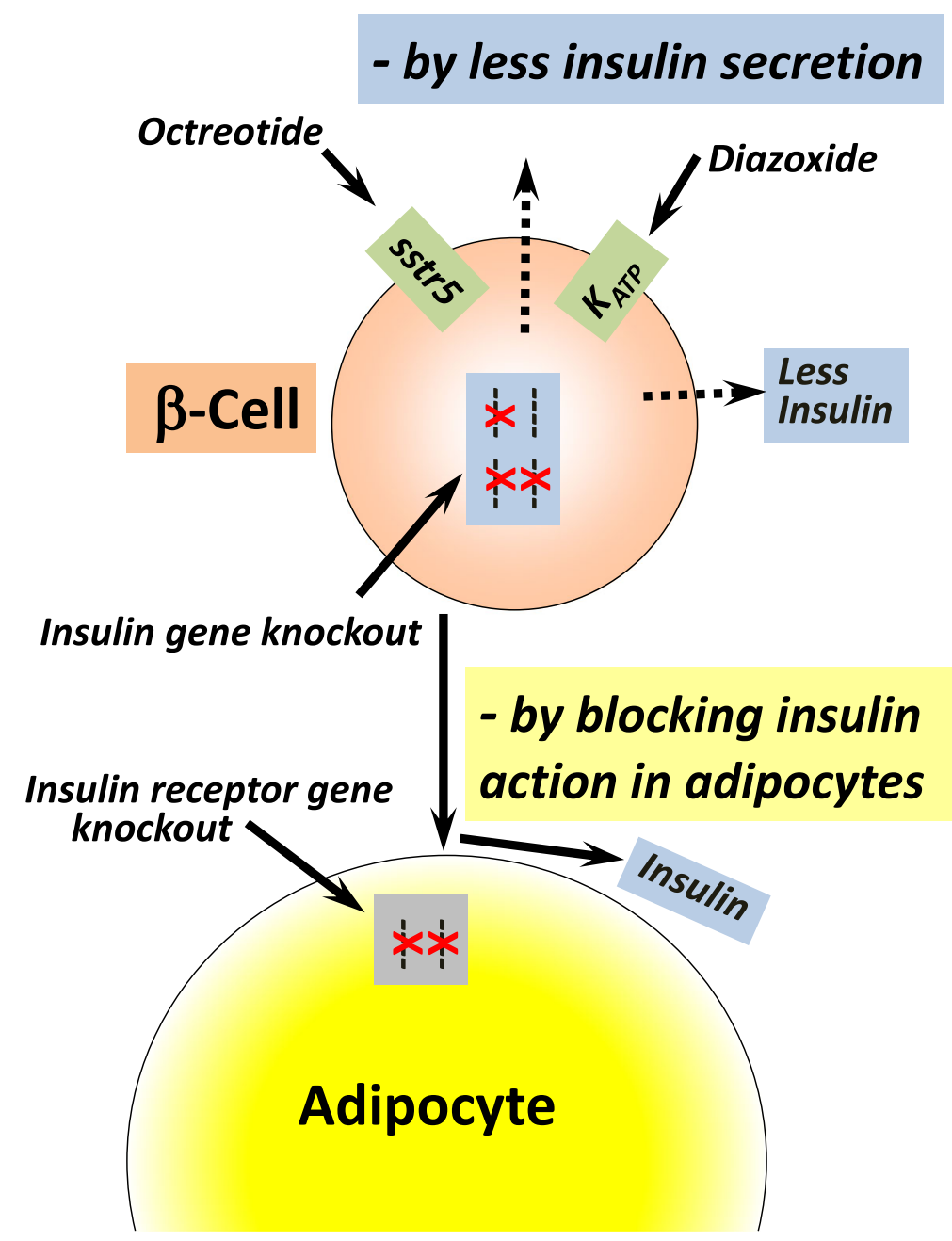

Fig. 1 Prevention/remission of obesity by targeting insulin or insulin action. In people who are obese, lowering insulin secretion by treatment with the $ß$-cell $\mathrm{K}_{\text {ATP }}$ channel opener diazoxide, or the long-acting somatostatin analogue octreotide, caused significant weight loss compared with the control group

More important is the observation that stimulating glucose uptake by insulin requires much higher hormone concentrations than is needed to inhibit lipolysis, even in the same individual. In five clamp studies, the mean insulin concentrations required to have a $50 \%$ effect (EC50) on the stimulation of peripheral glucose uptake were $\sim 720,480,348,360$ and $360 \mathrm{pmol} / \mathrm{l}$ (mean $=454$ pmol/l) $[64,65,67,74,75]$. Half maximal stimulation of glucose uptake required an insulin concentration that was about six times higher compared with that required for $50 \%$ inhibition of lipolysis (Fig. 2).

Suppression of hepatic glucose production also required higher insulin concentrations than lipolysis inhibition again, in part measured in the same individuals. EC50 values for insulin were $\sim 300,156,156,144,120,120$ $\mathrm{pmol} / \mathrm{l}($ mean $=170 \mathrm{pmol} / \mathrm{l})[63-65,67,74]$. Suppression of hepatic glucose output by $50 \%$ thus required more than twice the insulin concentration needed for half maximal inhibition of lipolysis (Fig. 2). To obtain the latter findings, insulin was infused at a peripheral vein to deliver a steady concentration of exogenous insulin to the liver via the arterial circulation. Usually, insulin is released from $B$-cells in discrete pulses, about every 5 minutes, with an amplitude of $0.5-1 \mathrm{nmol} / \mathrm{l}$ insulin in the fasted state and up to $5 \mathrm{nmol} / \mathrm{l}$ after a meal [76]. Of these high amounts of insulin, $50-80 \%$ is taken up by hepatocytes and does not therefore reach the peripheral circulation. Since hepatocytes can modulate the 


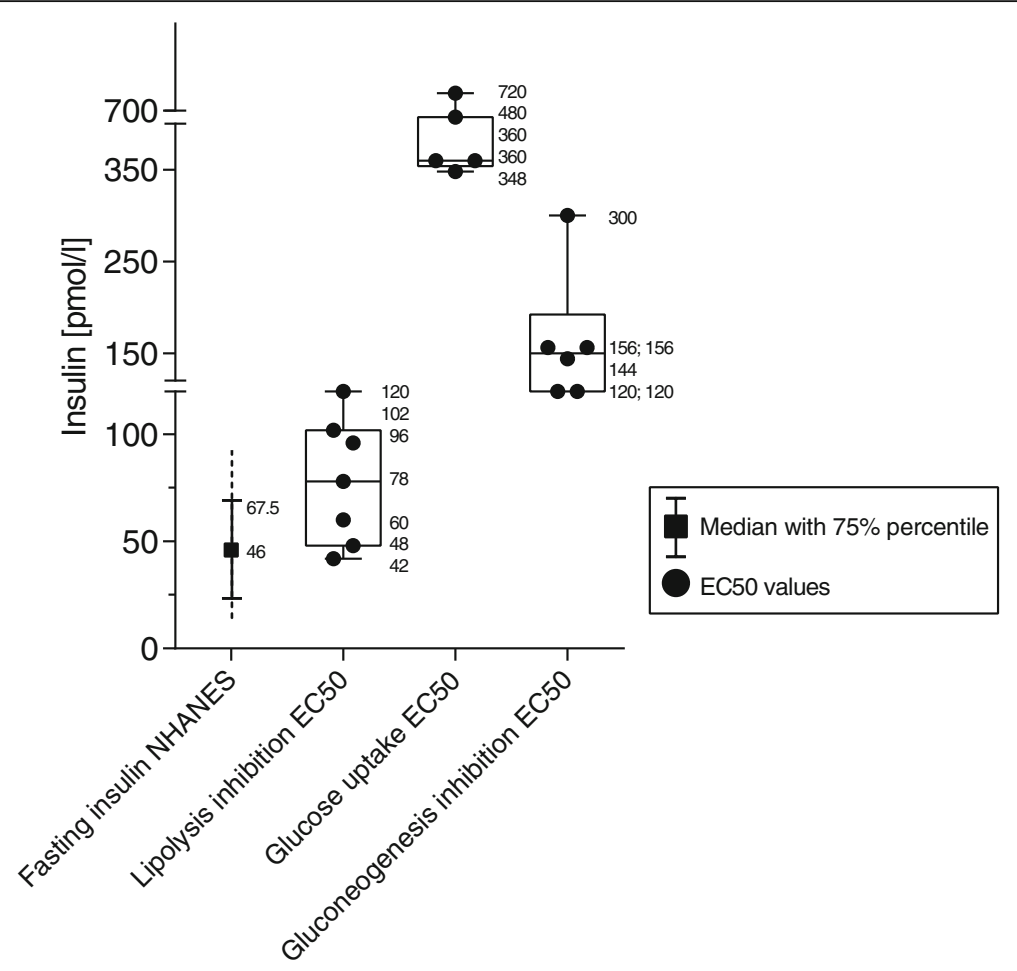

Fig. 2 Fasting insulin levels compared with EC50 values for lipolysis inhibition, glucose uptake induction or gluconeogenesis inhibition. Fasting insulin data are taken from the National Health and Nutrition Examination Survey (NHANES) 1986-1994 [71]. Numbers in rectangular boxes indicate mean insulin concentration for 50\% effect (EC50) on the stimulation of peripheral glucose uptake, as determined in different studies of non-obese adults. Mean insulin EC50 values for lipolysis inhibition were taken from $[63,64,66-69,113]$; mean EC50 values for the stimulation of glucose uptake were taken from $[64,65,67,74,75]$; and mean EC50 values for the inhibition of gluconeogenesis were taken from $[63-65,67,74]$

extent of insulin clearance, peripheral insulin levels are not only determined by ß-cell function [76, 77].

Taken together, evidence is compelling that insulin levels on the high side of normal, or which are slightly elevated, substantially inhibit lipolysis in the absence of relevant insulin actions on hepatic glucose production or on glucose transport into muscle. Even in high fasting plasma insulin concentrations, lipolysis inhibition is the most sensitive response to insulin (Fig. 2). Since lipolysis inhibition is equivalent to lipogenesis promotion, the effect of insulin on adipocytes is probably responsible for the observed association between hyperinsulinaemia and incident obesity. It also fits with the anti-obesity effects of lowering insulin levels with diazoxide or octreotide, and with the prevention or remission of obesity with genetic downregulation of insulin production or insulin receptor expression on adipocytes in mice. Studies in rodents also suggest that reducing circulating insulin levels by inactivating insulin genes or with diazoxide increases the basal metabolic rate by enhanced heat production from mitochondria during fat oxidation by uncoupling protein $1[54,78]$.

\section{Hyperinsulinaemia: the bigger picture}

Inhibition of lipolysis/promotion of lipogenesis, hepatic gluconeogenesis and glucose uptake into insulin-sensitive cells via upregulation of glucose transporter GLUT4 all require different levels of insulin to signal effectively via their receptors. Currently, the most probable explanation is the activation of different insulin signalling pathways in the different tissues, such as the PI3K-Akt pathway versus the MAP kinase pathway [79]. Insulin stimulates glucose transport via the canonical PI3K-Akt pathway, whereas lipolysis is suppressed via Akt-independent suppression of protein kinase A [80]. A further concept is that of selective insulin resistance. Indeed, insulin resistance affects glucose uptake but does not interfere with ChREBP-B-dependent de novo lipogenesis $[79,81]$.

It is not currently possible to disentangle the insulindependent regulatory network controlling body weight and weight increase. Insulin modifies its own activity [82] and interacts with other regulatory factors, such as other hormones, neuronal activity or gut function [8385]. Genetic components, such as putative thrifty genes and DNA sequences associated with obesity risk, add 
further complexity [86, 87]. It is therefore almost surprising that modulation of the systemic level of a single hormone, insulin, has such profound consequences on the risk of becoming obese. Insulin is our dominant anabolic hormone and, during an anabolic state of metabolism, cell stress is increased [20]. Insulin resistance is therefore considered a physiological defence to limit damage [88]. Low insulin levels extend the lifespan - at least in mice, possibly because of lower oxidative stress [89-91]. This effect was seen in the absence of altered IGF-1 levels and was associated with lower fasting glucose and improved insulin sensitivity.

The inverse association between insulin-mediated lipolysis and lipogenesis in adipocytes [62] means that decreased adipose tissue growth is accompanied by increased release of non-esterified free fatty acids (FFAs) from adipocyte triglycerides because of increased lipolysis. Systemic FFAs mostly come from upper body subcutaneous fat and do not reflect visceral adiposity [92]. Individual fasting FFA concentrations vary substantially - even if measured on consecutive days (coefficient of variation, $45 \%$, versus $4.8 \%$ for fasting glucose) [93]. One reason may be that the half-life of FFAs in the circulation is only $2-4$ minutes [94].

The epidemiological association between increased FFA levels after an overnight fast with metabolic and cardiovascular outcomes is not convincing, because the opposite has also been reported [94-96]. Women have FFA levels that are approximately 20\% higher than men, yet they have similar insulin sensitivity [92, 94]. Fasting FFA concentrations were not associated with several measures of insulin resistance or with liver fat accumulation [97].

In lean people, mean overnight fasting FFA concentrations ranges between 300 and $600 \mu \mathrm{mol} / \mathrm{l}$ [94]. Obese people with manifold higher fat mass exhibit marginally higher FFAs (difference $\sim 70 \mu \mathrm{mol} / \mathrm{l}$, mean of 43 studies) in the circulation [94]. This indicates that fat tissue releases fewer FFAs in obesity, attributed to downregulation of enzymes involved in the breakdown of triglycerides [98]. By contrast, FFA levels increased by $60 \%$ after 24 hours of severe energy restriction $(2.3 \mathrm{MJ})$ and reached around $1300 \mu \mathrm{mol} / \mathrm{l}$ after a 72-hour fast [94, 99]. Severe energy restriction of a similar magnitude $(2.5 \mathrm{MJ} /$ day) in T2DM patients has reportedly substantially improved metabolic health and even reverted clinical T2DM [100]. As expected, there was a decrease in plasma insulin levels by approximately one-third, reaching the level of non-diabetic controls, and a concomitant increase in systemic FFAs by $\sim 40 \%$. However, elevated FFA concentrations reverted to baseline levels within 8 weeks. Similarly, bariatric surgery lowered fasting insulin levels, accompanied by an increase of FFA concentrations, but FFA levels returned to baseline or lower after several months [101]. These findings indicate that humans adapt to lower insulin levels by normalising initially increased FFA levels.

\section{Conclusions}

Barbara Corkey introduced the concept of hyperinsulinaemia as a risk factor for obesity [102]. She suggested that environmental agents, such as food additives, toxins or excess iron, which have entered the food chain since 1980 , might cause insulin hypersecretion $[102,103]$. We report here that all lifestyle characteristics known to confer a risk of obesity are associated with hyperinsulinaemia. Any relationship between unfavourable lifestyle factors and high consumption of food additives or toxins at a global level remains unknown. Here, we suggest a mechanism for the association between hyperinsulinaemia and obesity, based on work mostly published in the 1980s. These studies concur in that much lower concentrations of insulin are required to inhibit lipolysis compared with gluconeogenesis or the promotion of glucose uptake (Fig. 2).

Interestingly, fasting insulin levels were much lower in lean vegetarians $($ mean $=30 \mathrm{pmol} / \mathrm{l})$ than in a lean case control group with similar energy and major nutrient intake $($ mean $=44 \mathrm{pmol} / \mathrm{l})$ and there was only a minor difference in fasting glucose values (means $=4.47$ versus $4.71 \mathrm{mmol} / \mathrm{l}$ ) [104]. Although insulin acts in virtually all tissues of the body, the low insulin levels of vegetarians are apparently sufficient to maintain the hormonal effects of insulin in the body. The very low basal insulin concentrations in vegetarians indicate that fasting insulin levels are modified by type of diet. The strongest effects are seen in people who follow very low calorie diets [100], intermittent fasting [105], or undergo bariatric surgery [106]. Dietary interventions are complicated by a diurnal pattern of insulin resistance, being lowest in the morning [107, 108]. Therefore, skipping breakfast has less favourable consequences than skipping dinner [109]. Physical exercise also reduces fasting insulin levels [7] (independently of weight change because it can be observed after a single exercise session) [110].

It may be insufficient to recognise prolonged hyperinsulinaemia by monitoring diurnal glucose levels. For instance, people with higher fasting insulin levels but normal glycaemia respond with higher postprandial insulin secretion than people with low basal insulin [111]. In healthy adults, oral glucose tolerance was not affected by the level of physical activity on the preceding day, but serum insulin levels during the glucose tolerance test were lower after high physical activity [112].

Taken together, the data presented justify the recommendation of a lifestyle that avoids high insulin levels for much of the day to limit the period of anabolic fat tissue activity (Box 1). 


\section{Box 1: Key points}

- All known lifestyle-dependent obesity risk factors are associated with, or give rise to, hyperinsulinaemia.

- Insulin levels that are on the high side of normal, or that are slightly elevated, predict later obesity in children and adolescents but not in adults.

- Pharmacological lowering of insulin secretion by diazoxide or octreotide causes weight loss.

- In mice, genetic lowering of insulin levels or selective genetic disruption of the insulin receptor in adipocytes causes prevention or remission of obesity.

- Lipolysis inhibition is the most sensitive metabolic action of insulin. Consequently, fasting insulin levels that are on the high side of normal, or that are slightly elevated, are sufficient to substantially inhibit lipolysis and the promotion of concomitant lipogenesis in adipocytes.

- Insulin concentrations that are six times higher than normal are required to stimulate glucose uptake and two times higher than normal to inhibit gluconeogenesis.

- It seems justified to suggest a lifestyle that avoids high insulin levels for much of the day to limit the period of anabolic fat tissue activity. Appropriate measures include low calorie diets, intermittent fasting or physical activity.

\section{Abbreviations}

BMI: Body mass index; EC50: Mean insulin concentration for 50\% effect; FFAs: Free fatty acids; T2DM: Type 2 diabetes mellitus

\section{Acknowledgements}

We thank Dr Fraser W Scott, University of Ottawa, for reading the manuscript.

\section{Funding}

Not applicable.

\section{Availability of data and materials}

Data for this review were identified by searching MEDLINE, PubMed and references from relevant articles using the search terms "lipolysis", "hyperinsulinemia", "adipocyte lipogenesis", "free fatty acids" OR "non esterified fatty acids", and "obesity". To limit the number of references, more recently published papers referring to several previously published articles were cited, if possible. Only articles published in English were selected.

\section{Authors' contributions \\ HK conducted the bibliographic research, wrote the initial and final drafts of the manuscript. SM conceived the manuscript and participated in writing the initial draft and manuscript review. MS, WK and KK reviewed the manuscript and contributed to writing the final version. SM had full access to all the data and had final responsibility for submitting the manuscript for publication. All the authors read and approved the final version of the manuscript.}

Ethics approval and consent to participate

Not applicable.

\section{Consent for publication}

Not applicable.

\section{Competing interests}

SM has received non-restricted support to conduct trials of lifestyle change in people who have, or are at risk of, T2DM by Novartis, Boehringer Ingelheim, Almased Wellness, Nintendo of Europe, HMM Holding, Gesellschaft von Freunden und Förderern der Heinrich-Heine-Universität Düsseldorf. Sponsors played no role in writing this manuscript or the decision to submit it for publication.

HK, MS, WK and KK declare that they have no competing interests.

\section{Publisher's Note}

Springer Nature remains neutral with regard to jurisdictional claims in published maps and institutional affiliations.

\section{Author details}

${ }^{1}$ Faculty of Medicine, University of Duesseldorf, Moorenstr. 5, 40225 Duesseldorf, Germany. ${ }^{2}$ West German Centre of Diabetes and Health, Duesseldorf Catholic Hospital Group, Hohensandweg 37, 40591 Duesseldorf, Germany. ${ }^{3}$ Department of Endocrinology and Nephrology, University of Leipzig, Liebigstraße 18, 04103 Leipzig, Germany. ${ }^{4}$ Biomedical and Scientific Consulting, 55130 Mainz, Germany.

Received: 23 September 2018 Accepted: 26 November 2018

\section{Published online: 13 December 2018}

\section{References}

1. NCD Risk Factor Collaboration (NCD-RisC). Worldwide trends in body-mass index, underweight, overweight, and obesity from 1975 to 2016: a pooled analysis of 2416 population-based measurement studies in 128.9 million children, adolescents, and adults. Lancet. 2017:390:2627-42.

2. NCD Risk Factor Collaboration (NCD-RisC). Trends in adult body-mass index in 200 countries from 1975 to 2014: a pooled analysis of 1698 populationbased measurement studies with 19.2 million participants. Lancet. 2016; 387:1377-96.

3. Kolb H, Martin S. Environmental/lifestyle factors in the pathogenesis and prevention of type 2 diabetes. BMC Med. 2017;15:131.

4. Herieka M, Erridge C. High-fat meal induced postprandial inflammation. Mol Nutr Food Res. 2014;58:136-46.

5. de Vries MA, Klop B, Janssen HW, Njo TL, Westerman EM, Castro CM. Postprandial inflammation: targeting glucose and lipids. Adv Exp Med Biol. 2014:824:161-70.

6. Boden G, Homko C, Barrero CA, Stein TP, Chen X, Cheung P, et al. Excessive caloric intake acutely causes oxidative stress, GLUT4 carbonylation, and insulin resistance in healthy men. Sci Transl Med. 2015;7:304re7.

7. Jelleyman C, Yates T, O'Donovan G, Gray L, King JA, Khunti K, et al. The effects of high-intensity interval training on glucose regulation and insulin resistance: a meta-analysis. Obes Rev. 2015;16:942-61.

8. Bowden Davies KA, Sprung VS, Norman JA, Thompson A, Mitchell KL, Halford JCG, et al. Short-term decreased physical activity with increased sedentary behaviour causes metabolic derangements and altered body composition: effects in individuals with and without a first-degree relative with type 2 diabetes. Diabetologia. 2018:61:1282-94.

9. Li H, Cai J, Chen R, Zhao Z, Ying Z, Wang L, et al. Particulate matter exposure and stress hormone levels: a randomized, double-blind, crossover trial of air purification. Circulation. 2017;136:618-27.

10. Donga E, van Dijk M, van Dijk JG, Biermasz NR, Lammers GJ, van Kralingen $\mathrm{KW}$, et al. A single night of partial sleep deprivation induces insulin resistance in multiple metabolic pathways in healthy subjects. J Clin Endocrinol Metab. 2010:95:2963-8.

11. Rao MN, Neylan TC, Grunfeld C, Mulligan K, Schambelan M, Schwarz JM. Subchronic sleep restriction causes tissue-specific insulin resistance. J Clin Endocrinol Metab. 2015;100:1664-71.

12. Wright KP Jr, Drake AL, Frey DJ, Fleshner M, Desouza CA, Gronfier C, et al. Influence of sleep deprivation and circadian misalignment on cortisol, inflammatory markers, and cytokine balance. Brain Behav Immun. 2015; 47:24-34.

13. Rao MN, Chau A, Madden E, Inslicht S, Talbot L, Richards A, et al. Hyperinsulinemic response to oral glucose challenge in individuals with posttraumatic stress disorder. Psychoneuroendocrinology. 2014;49:171-81.

14. Sun K, Liu J, Ning G. Active smoking and risk of metabolic syndrome: a meta-analysis of prospective studies. PLoS One. 2012;7:e47791. 
15. Piazzolla G, Castrovilli A, Liotino V, Vulpi MR, Fanelli M, Mazzocca A, et al. Metabolic syndrome and Chronic Obstructive Pulmonary Disease (COPD): the interplay among smoking, insulin resistance and vitamin D. PLoS One. 2017;12:e0186708.

16. Webb M, Davies M, Ashra N, Bodicoat D, Brady E, Webb D, et al. The association between depressive symptoms and insulin resistance, inflammation and adiposity in men and women. PLoS One. 2017;12:e0187448.

17. Bonaccio M, Di Castelnuovo A, Pounis G, De Curtis A, Costanzo S, Persichillo $M$, et al. Relative contribution of health-related behaviours and chronic diseases to the socioeconomic patterning of low-grade inflammation. Int Public Health. 2017;62:551-62.

18. Volaco A, Cavalcanti AM, Filho RP, Precoma DB. Socioeconomic status: the missing link between obesity and diabetes mellitus? Curr Diabetes Rev. 2018;14:321-6.

19. Kolb H, Mandrup-Poulsen T. The global diabetes epidemic as a consequence of lifestyle-induced low-grade inflammation. Diabetologia. 2010;53:10-20

20. Kolb H, Eizirik DL. Resistance to type 2 diabetes mellitus: a matter of hormesis? Nat Rev Endocrinol. 2011:8:183-92.

21. Spinas GA, Palmer JP, Mandrup-Poulsen T, Andersen H, Nielsen JH, Nerup J. The bimodal effect of interleukin 1 on rat pancreatic beta-cells--stimulation followed by inhibition--depends upon dose, duration of exposure, and ambient glucose concentration. Acta Endocrinol. 1988;119:307-11.

22. Arkan MC, Hevener AL, Greten FR, Maeda S, Li ZW, Long JM, et al. IKK-beta links inflammation to obesity-induced insulin resistance. Nat Med. 2005; 11:191-8.

23. Cai D, Yuan M, Frantz DF, Melendez PA, Hansen L, Lee J, et al. Local and systemic insulin resistance resulting from hepatic activation of IKK-beta and NF-kappaB. Nat Med. 2005;11:183-90.

24. Anagnostis P, Athyros VG, Tziomalos K, Karagiannis A, Mikhailidis DP. Clinical review: The pathogenetic role of cortisol in the metabolic syndrome: a hypothesis. J Clin Endocrinol Metab. 2009;94:2692-701.

25. Timper K, Bruning JC. Hypothalamic circuits regulating appetite and energy homeostasis: pathways to obesity. Dis Model Mech. 2017;10:679-89.

26. Douglass JD, Dorfman MD, Thaler JP. Glia: silent partners in energy homeostasis and obesity pathogenesis. Diabetologia. 2017;60:226-36.

27. Graupera M, Claret M. Endothelial Cells: New players in obesity and related metabolic disorders. Trends Endocrinol Metab. 2018;29:781-94.

28. Mace A, Tuke MA, Deelen P, Kristiansson K, Mattsson H, Noukas M, et al. CNV-association meta-analysis in 191,161 European adults reveals new loci associated with anthropometric traits. Nat Commun. 2017;8:744.

29. Mulders RJ, de Git KCG, Schele E, Dickson SL, Sanz Y, Adan RAH. Microbiota in obesity: interactions with enteroendocrine, immune and central nervous systems. Obes Rev. 2018;19:435-51.

30. Ertunc ME, Hotamisligil GS. Lipid signaling and lipotoxicity in metaflammation: indications for metabolic disease pathogenesis and treatment. J Lipid Res. 2016:57:2099-114.

31. Odeleye OE, de Courten M, Pettitt DJ, Ravussin E. Fasting hyperinsulinemia is a predictor of increased body weight gain and obesity in Pima Indian children. Diabetes. 1997;46:1341-5.

32. Morrison JA, Glueck CJ, Horn PS, Schreiber GB, Wang P. Pre-teen insulin resistance predicts weight gain, impaired fasting glucose, and type 2 diabetes at age 18-19 y: a 10-y prospective study of black and white girls. Am J Clin Nutr. 2008;88:778-88.

33. Adam TC, Toledo-Corral C, Lane CJ, Weigensberg MJ, Spruijt-Metz D, Davies $\mathrm{JN}$, et al. Insulin sensitivity as an independent predictor of fat mass gain in Hispanic adolescents. Diabetes Care. 2009;32:2114-5.

34. Labayen I, Ruiz JR, Ortega FB, Harro J, Merenakk L, Oja L, et al. Insulin sensitivity at childhood predicts changes in total and central adiposity over a 6-year period. Int J Obes. 2011;35:1284-8.

35. Chen YY, Wang JP, Jiang YY, Li H, Hu YH, Lee KO, et al. Fasting plasma insulin at 5 years of age predicted subsequent weight increase in early childhood over a 5-year period - the Da Qing Children Cohort Study. PLoS One. 2015;10:e0127389.

36. Sedaka NM, Olsen CH, Yannai LE, Stutzman WE, Krause AJ, SherafatKazemzadeh $\mathrm{R}$, et al. A longitudinal study of serum insulin and insulin resistance as predictors of weight and body fat gain in African American and Caucasian children. Int J Obes. 2017;41:61-70.

37. Howard BV, Adams-Campbell L, Allen C, Black H, Passaro M, Rodabough RJ, et al. Insulin resistance and weight gain in postmenopausal women of diverse ethnic groups. Int J Obes Relat Metab Disord. 2004;28:1039-47.
38. Hoag S, Marshall JA, Jones RH, Hamman RF. High fasting insulin levels associated with lower rates of weight gain in persons with normal glucose tolerance: the San Luis Valley Diabetes Study. Int J Obes Relat Metab Disord. 1995:19:175-80.

39. Wedick NM, Snijder MB, Dekker JM, Heine RJ, Stehouwer CD, Nijpels G, et al. Prospective investigation of metabolic characteristics in relation to weight gain in older adults: the Hoorn Study. Obesity. 2009;17:1609-14.

40. Swinburn BA, Nyomba BL, Saad MF, Zurlo F, Raz I, Knowler WC, et al. Insulin resistance associated with lower rates of weight gain in Pima Indians. J Clin Invest. 1991;88:168-73.

41. Valdez R, Mitchell BD, Haffner SM, Hazuda HP, Morales PA, Monterrosa A, et al. Predictors of weight change in a bi-ethnic population. The San Antonio Heart Study. Int J Obes Relat Metab Disord. 1994;18:85-91.

42. Morrison JA, Glueck CJ, Wang P. Preteen insulin levels interact with caloric intake to predict increases in obesity at ages 18 to 19 years: a 10-year prospective study of black and white girls. Metabolism. 2010;59:718-27.

43. Doyle ME, Egan JM. Pharmacological agents that directly modulate insulin secretion. Pharmacol Rev. 2003;55:105-31.

44. Alemzadeh R, Langley G, Upchurch L, Smith P, Slonim AE. Beneficial effect of diazoxide in obese hyperinsulinemic adults. J Clin Endocrinol Metab. 1998:83:1911-5.

45. Due A, Flint A, Eriksen G, Moller B, Raben A, Hansen JB, et al. No effect of inhibition of insulin secretion by diazoxide on weight loss in hyperinsulinaemic obese subjects during an 8-week weight-loss diet. Diabetes Obes Metab. 2007:9:566-74.

46. Velasquez-Mieyer PA, Cowan PA, Arheart KL, Buffington CK, Spencer KA, Connelly $\mathrm{BE}$, et al. Suppression of insulin secretion is associated with weight loss and altered macronutrient intake and preference in a subset of obese adults. Int J Obes Relat Metab Disord. 2003;27:219-26.

47. Lustig RH, Greenway F, Velasquez-Mieyer P, Heimburger D, Schumacher D, Smith D, et al. A multicenter, randomized, double-blind, placebo-controlled, dose-finding trial of a long-acting formulation of octreotide in promoting weight loss in obese adults with insulin hypersecretion. Int Obes. 2006:30:331-41.

48. Hu S, Xu Z, Yan J, Liu M, Sun B, Li W, et al. The treatment effect of diazoxide on 44 patients with congenital hyperinsulinism. J Pediatr Endocrinol Metab. 2012;25:1119-22.

49. Pivonello R, Muscogiuri G, Holder G, Paul M, Sarp S, Lesogor A, et al. Longterm safety of long-acting octreotide in patients with diabetic retinopathy: results of pooled data from 2 randomized, double-blind, placebo-controlled phase 3 studies. Endocrine. 2018;60:65-72.

50. Hodish I. Insulin therapy, weight gain and prognosis. Diabetes Obes Metab. 2018;20:2085-92.

51. Kullmann S, Heni M, Hallschmid M, Fritsche A, Preissl H, Haring HU. Brain insulin resistance at the crossroads of metabolic and cognitive disorders in humans. Physiol Rev. 2016;96:1169-209.

52. Jauch-Chara K, Friedrich A, Rezmer M, Melchert UH, Scholand-Engler G, Hallschmid M, et al. Intranasal insulin suppresses food intake via enhancement of brain energy levels in humans. Diabetes. 2012;61:2261-8.

53. Benedict $C$, Brede $S$, Schioth HB, Lehnert $H$, Schultes B, Born J, et al. Intranasal insulin enhances postprandial thermogenesis and lowers postprandial serum insulin levels in healthy men. Diabetes. 2011;60:114-8.

54. Mehran AE, Templeman NM, Brigidi GS, Lim GE, Chu KY, Hu X, et al. Hyperinsulinemia drives diet-induced obesity independently of brain insulin production. Cell Metab. 2012;16:723-37.

55. Templeman NM, Clee SM, Johnson JD. Suppression of hyperinsulinaemia in growing female mice provides long-term protection against obesity. Diabetologia. 2015;58:2392-402.

56. Page MM, Skovso S, Cen H, Chiu AP, Dionne DA, Hutchinson DF, et al. Reducing insulin via conditional partial gene ablation in adults reverses diet-induced weight gain. FASEB J. 2018:32:1196-206.

57. Bluher M, Michael MD, Peroni OD, Ueki K, Carter N, Kahn BB, et al. Adipose tissue selective insulin receptor knockout protects against obesity and obesity-related glucose intolerance. Dev Cell. 2002;3:25-38.

58. Edghill EL, Flanagan SE, Patch AM, Boustred C, Parrish A, Shields B, et al. Insulin mutation screening in 1,044 patients with diabetes: mutations in the INS gene are a common cause of neonatal diabetes but a rare cause of diabetes diagnosed in childhood or adulthood. Diabetes. 2008:57:1034-42.

59. Molven A, Ringdal M, Nordbo AM, Raeder H, Stoy J, Lipkind GM, et al. Mutations in the insulin gene can cause MODY and autoantibody-negative type 1 diabetes. Diabetes. 2008;57:1131-5. 
60. Kleinberger JW, Copeland KC, Gandica RG, Haymond MW, Levitsky LL, Linder $\mathrm{B}$, et al. Monogenic diabetes in overweight and obese youth diagnosed with type 2 diabetes: the TODAY clinical trial. Genet Med. 2018;20:583-90

61. Blundell JE, Dulloo AG, Salvador J, Fruhbeck G. Beyond BMI - phenotyping the obesities. Obes Facts. 2014;7:322-8.

62. Thomas $\mathrm{SH}$, Wisher $\mathrm{MH}$, Brandenburg D, Sonksen PH. Insulin action on adipocytes. Evidence that the anti-lipolytic and lipogenic effects of insulin are mediated by the same receptor. Biochem J. 1979;184:355-60.

63. Nurjhan N, Campbell PJ, Kennedy FP, Miles JM, Gerich JE. Insulin doseresponse characteristics for suppression of glycerol release and conversion to glucose in humans. Diabetes. 1986;35:1326-31.

64. Groop LC, Bonadonna RC, DelPrato S, Ratheiser K, Zyck K, Ferrannini E, et al. Glucose and free fatty acid metabolism in non-insulin-dependent diabetes mellitus. Evidence for multiple sites of insulin resistance. J Clin Invest. 1989; 84:205-13.

65. Bonadonna RC, Groop L, Kraemer N, Ferrannini E, Del Prato S, DeFronzo RA. Obesity and insulin resistance in humans: a dose-response study. Metabolism. 1990;39:452-9.

66. Groop LC, Bonadonna RC, Simonson DC, Petrides AS, Shank M, DeFronzo RA. Effect of insulin on oxidative and nonoxidative pathways of free fatty acid metabolism in human obesity. Am J Physiol. 1992;263:E79-84.

67. Campbell PJ, Mandarino LJ, Gerich JE. Quantification of the relative impairment in actions of insulin on hepatic glucose production and peripheral glucose uptake in non-insulin-dependent diabetes mellitus. Metabolism. 1988;37:15-21.

68. Campbell PJ, Carlson MG, Hill JO, Nurjhan N. Regulation of free fatty acid metabolism by insulin in humans: role of lipolysis and reesterification. Am J Physiol. 1992;263:E1063-9.

69. Stumvoll M, Jacob S. Multiple sites of insulin resistance: muscle, liver and adipose tissue. Exp Clin Endocrinol Diabetes. 1999;107:107-10.

70. Jacob S, Hauer B, Becker R, Artzner S, Grauer P, Loblein K, et al. Lipolysis in skeletal muscle is rapidly regulated by low physiological doses of insulin. Diabetologia. 1999:42:1171-4.

71. Li C, Ford ES, McGuire LC, Mokdad AH, Little RR, Reaven GM. Trends in hyperinsulinemia among nondiabetic adults in the U.S. Diabetes Care. 2006; 29:2396-402.

72. Taylor R. Insulin resistance and type 2 diabetes. Diabetes. 2012;61:778-9.

73. Yeni-Komshian H, Carantoni M, Abbasi F, Reaven GM. Relationship between several surrogate estimates of insulin resistance and quantification of insulin-mediated glucose disposal in 490 healthy nondiabetic volunteers. Diabetes Care. 2000;23:171-5.

74. DeFronzo RA, Ferrannini E, Hendler R, Felig P, Wahren J. Regulation of splanchnic and peripheral glucose uptake by insulin and hyperglycemia in man. Diabetes. 1983;32:35-45.

75. Prager $\mathrm{R}$, Wallace $P$, Olefsky JM. In vivo kinetics of insulin action on peripheral glucose disposal and hepatic glucose output in normal and obese subjects. J Clin Invest. 1986;78:472-81.

76. Tokarz VL, MacDonald PE, Klip A. The cell biology of systemic insulin function. J Cell Biol. 2018;217:2273-89.

77. Jung SH, Jung $\mathrm{CH}$, Reaven GM, Kim SH. Adapting to insulin resistance in obesity: role of insulin secretion and clearance. Diabetologia. 2018;61:681-7.

78. Alemzadeh R, Karlstad MD, Tushaus K, Buchholz M. Diazoxide enhances basal metabolic rate and fat oxidation in obese Zucker rats. Metabolism. 2008;57:1597-607

79. Williams KJ, Wu X. Imbalanced insulin action in chronic over nutrition: Clinical harm, molecular mechanisms, and a way forward. Atherosclerosis. 2016;247:225-82

80. Choi SM, Tucker DF, Gross DN, Easton RM, DiPilato LM, Dean AS, et al. Insulin regulates adipocyte lipolysis via an Akt-independent signaling pathway. Mol Cell Biol. 2010;30:5009-20.

81. Eissing L, Scherer T, Todter K, Knippschild U, Greve JW, Buurman WA, et al. De novo lipogenesis in human fat and liver is linked to ChREBP-beta and metabolic health. Nat Commun. 2013;4:1528.

82. Del Prato S, Leonetti F, Simonson DC, Sheehan P, Matsuda M, DeFronzo RA Effect of sustained physiologic hyperinsulinaemia and hyperglycaemia on insulin secretion and insulin sensitivity in man. Diabetologia. 1994; 37:1025-35.

83. Hotamisligil GS. Inflammation, metaflammation and immunometabolic disorders. Nature. 2017;542:177-85.
84. Torres-Fuentes C, Schellekens H, Dinan TG, Cryan JF. The microbiota-gutbrain axis in obesity. Lancet Gastroenterol Hepatol. 2017;2:747-56.

85. Pan WW, Myers MG Jr. Leptin and the maintenance of elevated body weight. Nat Rev Neurosci. 2018;19:95-105.

86. Loos RJ. The genetics of adiposity. Curr Opin Genet Dev. 2018:50:86-95.

87. Qasim A, Turcotte M, de Souza RJ, Samaan MC, Champredon D, Dushoff J, et al. On the origin of obesity: identifying the biological, environmental and cultural drivers of genetic risk among human populations. Obes Rev. 2018; 19:121-49.

88. Nolan CJ, Ruderman NB, Kahn SE, Pedersen O, Prentki M. Insulin resistance as a physiological defense against metabolic stress: implications for the management of subsets of type 2 diabetes. Diabetes. 2015;64:673-86.

89. DiLoreto R, Murphy CT. The cell biology of aging. Mol Biol Cell. 2015;26: 4524-31.

90. Azzu V, Valencak TG. Energy metabolism and ageing in the mouse: a minireview. Gerontology. 2017:63:327-36.

91. Templeman NM, Flibotte S, Chik JHL, Sinha S, Lim GE, Foster L, et al. Reduced circulating insulin enhances insulin sensitivity in old mice and extends lifespan. Cell Rep. 2017;20:451-63.

92. Shadid S, Kanaley JA, Sheehan MT, Jensen MD. Basal and insulin-regulated free fatty acid and glucose metabolism in humans. Am J Physiol Endocrinol Metab. 2007;292:E1770-4.

93. Widjaja A, Morris RJ, Levy JC, Frayn KN, Manley SE, Turner RC. Within- and between-subject variation in commonly measured anthropometric and biochemical variables. Clin Chem. 1999:45:561-6.

94. Karpe F, Dickmann JR, Frayn KN. Fatty acids, obesity, and insulin resistance: time for a reevaluation. Diabetes. 2011;60:2441-9.

95. Il'yasova D, Wang F, D'Agostino RB Jr, Hanley A, Wagenknecht LE. Prospective association between fasting NEFA and type 2 diabetes: impact of post-load glucose. Diabetologia. 2010;53:866-74

96. Byrne CD, Maison P, Halsall D, Martensz N, Hales CN, Wareham NJ. Crosssectional but not longitudinal associations between non-esterified fatty acid levels and glucose intolerance and other features of the metabolic syndrome. Diabet Med. 1999;16:1007-15.

97. Finucane FM, Sharp SJ, Hatunic M, Sleigh A, De Lucia RE, Sayer AA, et al. Intrahepatic lipid content and insulin resistance are more strongly associated with impaired NEFA suppression after oral glucose loading than with fasting NEFA levels in healthy older individuals. Int J Endocrinol. 2013; 2013:870487.

98. Jocken JW, Langin D, Smit E, Saris WH, Valle C, Hul GB, et al. Adipose triglyceride lipase and hormone-sensitive lipase protein expression is decreased in the obese insulin-resistant state. J Clin Endocrinol Metab. 2007:92:2292-9.

99. Clayton DJ, Burrell K, Mynott G, Creese M, Skidmore N, Stensel DJ, et al. Effect of 24-h severe energy restriction on appetite regulation and ad libitum energy intake in lean men and women. Am J Clin Nutr. 2016; 104:1545-53.

100. Lim EL, Hollingsworth KG, Aribisala BS, Chen MJ, Mathers JC, Taylor R. Reversal of type 2 diabetes: normalisation of beta cell function in association with decreased pancreas and liver triacylglycerol. Diabetologia. 2011;54:2506-14.

101. Carswell KA, Belgaumkar AP, Amiel SA, Patel AG. A systematic review and meta-analysis of the effect of gastric bypass surgery on plasma lipid levels. Obes Surg. 2016;26:843-55.

102. Corkey BE. Banting lecture 2011: hyperinsulinemia: cause or consequence? Diabetes. 2012;61:4-13.

103. Erion KA, Corkey BE. Hyperinsulinemia: a cause of obesity? Curr Obes Rep. 2017;6:178-86.

104. Valachovicova M, Krajcovicova-Kudlackova M, Blazicek P, Babinska K. No evidence of insulin resistance in normal weight vegetarians. A case control study. Eur J Nutr. 2006:45:52-4.

105. Longo VD, Panda S. Fasting, circadian rhythms, and time-restricted feeding in healthy lifespan. Cell Metab. 2016;23:1048-59.

106. Pories WJ, Dohm GL. Diabetes: have we got it all wrong? Hyperinsulinism as the culprit: surgery provides the evidence. Diabetes Care. 2012;35:2438-42.

107. Saad A, Dalla MC, Nandy DK, Levine JA, Bharucha AE, Rizza RA, et al. Diurnal pattern to insulin secretion and insulin action in healthy individuals. Diabetes. 2012:61:2691-700.

108. Basse AL, Dalbram E, Larsson L, Gerhart-Hines Z, Zierath JR, Treebak JT. Skeletal muscle insulin sensitivity show circadian rhythmicity which is independent of exercise training status. Front Physiol. 2018;9:1198. 
109. Nas A, Mirza N, Hagele F, Kahlhofer J, Keller J, Rising R, et al. Impact of breakfast skipping compared with dinner skipping on regulation of energy balance and metabolic risk. Am J Clin Nutr. 2017;105:1351-61.

110. Short KR, Pratt LV, Teague AM. A single exercise session increases insulin sensitivity in normal weight and overweight/obese adolescents. Pediatr Diabetes. 2018. https://doi.org/10.1111/pedi.12684.

111. Garnett SP, Srinivasan S, Birt SG, Ambler GR, Lawrie EA, Cowell CT, et al. Evaluation of glycaemic status in young people with clinical insulin resistance; fasting glucose, fasting insulin or an oral glucose tolerance test? Clin Endocrinol. 2010;72:475-80.

112. Timmerman KL, Ballard KD, Volk GA, Deal MA, Meisler AJ, Karrow JM, et al. Altering physical activity influences insulin responses to glucose ingestion in healthy adults. Int J Sports Med. 2018. https://doi.org/10.1055/a-0735-9641.

113. Bonadonna RC, Groop LC, Zych K, Shank M, DeFronzo RA. Dose-dependent effect of insulin on plasma free fatty acid turnover and oxidation in humans. Am J Physiol. 1990;259:E736-50.

114. Iggman D, Rosqvist F, Larsson A, Arnlov J, Beckman L, Rudling M, et al. Role of dietary fats in modulating cardiometabolic risk during moderate weight gain: a randomized double-blind overfeeding trial (LIPOGAIN study). J Am Heart Assoc. 2014;3:e001095.

115. Nilsson A, Bergens O, Kadi F. Physical activity alters inflammation in older adults by different intensity levels. Med Sci Sports Exerc. 2018;50:1502-7.

116. Jiang S, Bo L, Gong C, Du X, Kan H, Xie Y, et al. Traffic-related air pollution is associated with cardio-metabolic biomarkers in general residents. Int Arch Occup Environ Health. 2016;89:911-21.

117. Cai Y, Hansell AL, Blangiardo M, Burton PR, de Hoogh K, Doiron D, et al. Long-term exposure to road traffic noise, ambient air pollution, and cardiovascular risk factors in the HUNT and lifelines cohorts. Eur Heart J. 2017;38:2290-6.

Ready to submit your research? Choose BMC and benefit from:

- fast, convenient online submission

- thorough peer review by experienced researchers in your field

- rapid publication on acceptance

- support for research data, including large and complex data types

- gold Open Access which fosters wider collaboration and increased citations

- maximum visibility for your research: over $100 \mathrm{M}$ website views per year

At $\mathrm{BMC}$, research is always in progress.

Learn more biomedcentral.com/submissions 